\title{
Audiovisual enclosures in Jim Jarmusch's The limits of control
}

Zettl, Nepomuk Baptist

Posted at the Zurich Open Repository and Archive, University of Zurich ZORA URL: https://doi.org/10.5167/uzh-140609

Book Section

Published Version

Originally published at:

Zettl, Nepomuk Baptist (2017). Audiovisual enclosures in Jim Jarmusch's The limits of control. In: Heboyan, Esther. Les variations Jarmusch. Arras, France: Artois Presses Université, 101-115. 


\title{
AUDIOVISUAL ENCLOSURES IN JIM JARMUSCH'S THE LIMITS OF CONTROL
}

\author{
Nepomuk Zettl \\ University of Zurich
}

"The ineffable element of the dream within"

$\mathrm{O}$ n April 29, 2006, Tilda Swinton gave a speech at the $49^{\text {th }}$ San Francisco Film Festival on the state of cinema. On the occasion of the annual address, she did not deliver a flaming talk on the industry, but read a letter to her son, who had recently asked her - at the symbolic age of eight and a half - "what people's dreams were like before the cinema was invented"1.

Swinton, struggling with a reply to this intricate question, elaborated so eloquently on the comparison of dream and film that Jim Jarmusch took up lines from her speech and adapted them in his 2009 film The Limits of Control ${ }^{2}$. The following passage is taken from the very heart of the letter:

Film is the art-form through which time becomes material. Now more than ever, perhaps, we need its possibilities and the sincerity of its witness. In this period where we are attacking and dismantling time itself through our fascination with the virtual and with the simultaneous, we now long for new - renewed - experiences of the temporal, an existential sensation of duration. Why?

\footnotetext{
'Tilda Swinton, "A Letter to a Boy from His Mother", Critical Quarterly 48.3, Autumn 2006, p. 110.

${ }^{2}$ Cf. Q\&A with Jim Jarmusch, The Film Society of Lincoln Center: "Archival Talks: Jim Jarmusch, The Limits of Control", 30 October 2009. <https://www.youtube.com/ watch? $\mathrm{v}=\mathrm{v} 62 \mathrm{aGp} 0 \mathrm{v} 64 \mathrm{k}>$ Accessed 31 May 2015, 39:30 - 40:21.
} 
Perhaps it is to do with memory and the sense that we are increasingly being pulled into a vast orchestrated project of amnesia. We discovered cinema in the same moment in history when we rediscovered - through Freud - the significance of our dreams. Now we are displacing and distorting - with our passion for genetics, neuroscience, cognitivism - the ineffable element of the dream within the machine. Our dreams are the place where we can remember that which we never realized we knew. ${ }^{3}$

In this passage, Tilda Swinton refers to a remarkable metaphor - the "machine" - as a location for dreams. By doing so, she suggests a mechanism underlying both dreams and cinema ${ }^{4}$ that cannot be expressed or described properly. She locates dreaming in a "machine", producing a consciousness of the incorporation of memory. Thus, when she describes "dreams" as "the place where we can remember that which we never realized we knew", she ascribes dreaming not only a spatial dimension but also a temporal dimension. And it is film that witnesses the materialization of what was recorded in the past ${ }^{5}$.

This essay sets out to trace such locations "of the dream within the machine" in Jim Jarmusch's The Limits of Control. It investigates material objects that introduce hors-champ spaces into the diegesis and hint at virtual contexts. Certainly, no attempt will be made to describe "the ineffable element of the dream", but it will be shown that Jarmusch uses specific enclosures to develop a motif - similarly to Swinton's use of "the machine" - in order to reflect on cinema: on a thematic level, by staging characters' monologues (on the memory of instruments, movies, music, molecular detection, etymology, and hallucinations), and theorizing acoustics, the (in)visible, memory, and perception; and on a formal level, by highlighting the modes of representation in the mise-en-scène.

\footnotetext{
${ }^{3}$ Tilda Swinton, ibid., p.118f. Cf. Sigmund Freud's Interpretation of Dreams (1900), The Standard Edition of the Complete Psychological Works of Sigmund Freud IV.1, London: Hogarth, 1964, pp. 11 and 14.

${ }^{4}$ See Jean Epstein, L'intelligence d'une machine, Paris: Jacques Melot, 1946, p. 55: “[L] es procédés qu'emploie le discours du rêve et qui lui permettent sa sincérité profonde, trouvent leurs analogues dans le style cinématographique."

${ }^{5}$ Sigmund Freud, ibid., p. 11: "We are thus driven to admit that in the dream we knew and remembered something which was beyond the reach of our waking memory." Films are on the edge between dream and waking reality, fulfilling the longing to attain knowledge in dreams. They enable access to spaces not necessarily related to our experience, which expands our horizon over a fixed period of time.
} 


\section{Enclosures}

To call the cinematic apparatus a machine emphasizes underlying mechanisms that constitute film and its perception ${ }^{6}$. Nevertheless, objects inviting a reflection on the medium are hardly limited to the shape of a machine. In Jarmusch's earlier film Ghost Dog (1999), often associated with The Limits of $\mathrm{Control}^{7}$, reflection on the medium is initiated by a bag.

Wherever the samurai hit man Ghost Dog (Forest Whitaker) goes, he carries along a black briefcase containing weapons, a box that magically opens doors for him, and the book he uses as a guideline: Yamamoto Tsunetomo's Hagakure: The Book of the Samurai. As he begins his campaign against the criminal organization, Ghost Dog is shown in a montage that equates him to the comic icon Felix the Cat. As he walks from right to left in a dark street with his briefcase in one hand and a rifle case in the other, the walking movement is taken up by Felix the Cat, who appears on a TV screen in the next scene ${ }^{8}$. The head of the organization in front of the TV (Henry Silva) is mirrored by the cat's antagonist, the Mad Professor, summing up the basic plot of the TV series: the professor's repeated attempts to steal the bag simply because "it's magic and more magic". But the magic cannot be found inside the bag. The bag itself undergoes transformations that are "magical" and that turn the bag into a fetish ${ }^{10}$. On screen, prior to the magical alteration of his bag, Felix utters what his bag is supposed to turn into; he anticipates the shape the bag will assume. Consequently, Felix's imagination turns into image.

"Ghost Dog is also an extremely self-conscious text about other texts that it references and reworks" ${ }^{\prime 1}$. Accordingly, it creates its own philosophy around the books that are presented within the film ${ }^{12}$. The most important of these texts is Tsunetomo's Hagakure - with passages of it appearing in close-up, literally providing a reading of the film's action - and Rashōmon by Ryūnosuke Akutagawa. These books are eventually carried around in the lunchbox of

\footnotetext{
${ }^{6}$ See Jean-Louis Baudry, "Ideological Effects of the Basic Cinematographic Apparatus", Film Quarterly 28.2, 1974-75, pp. 39-47.

${ }^{7}$ Julian Rice, The Jarmusch Way: Spirituality and Imagination in Dead Man, Ghost Dog and The Limits of Control, Lanham: Scarecrow, 2012; Sofia Glasl, Mind the Map, Marburg: Schüren, 2014.

${ }^{8}$ See John Canemaker, Felix: The Twisted Tale of the World's Most Famous Cat, New York: Da Capo, 1996, p. $150 f$.

9 Jim Jarmusch, Ghost Dog (1999), Kinowelt Home Entertainment, 2005, 00:59:47 01:00:33.

${ }^{10}$ Hartmut Böhme, Fetishism and Culture, trans. Anna Galt, Berlin and Boston: Walter de Gruyter, 2014.

${ }^{11}$ Juan A. Suárez, Jim Jarmusch, Urbana and Chicago: University of Illinois Press, 2007, p. 126.

${ }^{12}$ See Julian Rice, ibid., p. 23.
} 
Pearline - the spiritual heir of the protagonist ${ }^{13}$. Her lunchbox encloses a set of books that, when opened up, inspire imagination through a series of words and sentences, with the horizon of the reader expanding with every flick of the page. And while Ghost Dog carries his book in a briefcase, a travel bag similar to that of Felix the Cat turns up once again in The Limits of Control.

The opaque surfaces of these containers - Swinton's machine, the bag, or the lunchbox - create something one could call the "Pandora principle". They render a visual trace of an element that eludes the grasp at present - like an unopened box, a rifle that has not yet been fired, or a guitar string that might both carry a tune and serve as a potential murder weapon. As motifs ${ }^{14}$, they hint at contexts and might even carry the potential of a subversive dimension to the film.

\section{The Ineffable in The Limits of Control}

In Jarmusch's The Limits of Control, "the ineffable element of the dream" is also located in a recurring object. On his trip, the protagonist (Isaach De Bankolé), who is simply titled Lone Man, exchanges matchboxes in seemingly coincidental encounters. The film begins with a first matchbox being handed over at the airport and ends with Lone Man disposing of the last one. The repetitive exchange of matchboxes becomes a consistent motif in The Limits of Control ${ }^{15}$. With one exception, each of them contains a piece of paper with a coded message, accompanied by an enigmatic monologue delivered by the contact. Some guide the nameless protagonist to another city, but all of them instruct him to wait and be found. In this limbo, shared by the audience, sonic and visual details outweigh the importance of dramatic action.

As the linear plot advances, there are no sidelines to the story. The protagonist's path is prearranged, and because there is no causal link between them, each scene can be regarded as an implicit directive to perceive consciously, with parameters changing in every encounter. In the entanglement of a material object with an opaque instruction, the object used to illustrate the monologues is altered from an icon into a symbol ${ }^{16}$, unfolding a particular meaning in

${ }^{13}$ Jim Jarmusch, Ghost Dog (1999), Kinowelt Home Entertainment, 2005, 00:36:57 00:39:20. Cf. Julian Rice, p. 21.

${ }^{14}$ Emmanuelle André, Esthétique du motif. Cinéma musique peinture, Paris: Presses Universitaires de Vincennes, 2007. See also Kenneth Burke, A Rhetoric of Motives, New York: Prentice-Hall, 1950; Lorenz Engell and André Wendler, "Medienwissenschaft der Motive", Zeitschrift für Medienwissenschaft 1, 2009, pp. 38-49.

${ }^{15}$ A central motif in The Limits of Control, the Boxeur matchbox becomes more than "a little tribute to Claire Denis' White Material (2009). James Mottram, "Theme and Variations", Sight and Sound 20.1, 2010, p. 16.

${ }^{16}$ Gilles Deleuze, Cinema II: The Time-Image, Minneapolis: University of Minnesota Press, 1989, p. 32f; Charles S. Peirce, The Writings of Charles Sanders Peirce: A 
the following sequence ${ }^{17}$. Hence, each contact's monologue is like a coded message, a plain surface that gains depth - over time - by being decoded.

If the instructions at the end of each monologue direct attention, the monologues themselves shape perception. During the first encounter, a man carrying a violin case (Luis Tosar) utters a theory on the memory of instruments:

I believe that musical instruments, especially those made out of wood - cellos, violins, guitars - I believe that they resonate, musically, even when they're not being played. They have a memory. Every note that's ever been played on them is still inside of them, resonating in the molecules of the wood. I guess like everything it's a matter of perception, no? ${ }^{18}$

He is providing a concept of memory transcending time in locating the past - faded intervals of sound - in a resonating body that translates time into space. He uses acoustics and musical instruments as a figure of thought, as a medium to illustrate the simultaneous.

In choosing an acoustic analogy to illustrate a memory mechanism, Jarmusch has a significant predecessor. The philosopher Henri Bergson may have created a schema to visualize the relationship between perception and memory in Matière et mémoire (Matter and Memory) ${ }^{19}$, published in the same year as the promising arrival of the Lumière brothers' train, but he deliberately uses an acoustic metaphor for illustrating the simultaneous:

It is like an immense keyboard, on which the external object executes at once its harmony of a thousand notes, thus calling forth in a definite order, and at a single moment, a great multitude of elementary sensations corresponding to all the points of the sensory centre that are concerned. ${ }^{20}$

So the past lies enclosed in memories as well as in material objects. The acoustic metaphor of a resonating body carries a latent quality that is not

Chronological Edition V(1884 - 1886), Bloomington: Indiana University Press, 1993, p. 243.

${ }^{17}$ See Jean Epstein, "The Cinematograph, Machine of Dreams", Jean Epstein: Critical Essays and New Translations, Amsterdam: Amsterdam University Press, 2012, p. 315: "[T] he action of the dream, like that of the film, unrolls each at its own pace, cut up and recognized again ad libitum, where the simultaneous can be drawn out to succession, and the successive can be compressed and happen at the same time, to the extent that the difference from exterior time may go all the way to inversion."

${ }^{18} \mathrm{Jim}$ Jarmusch, The Limits of Control (2009), Universum Film, 2009, 00:21:08 00:21:53 (originally in Spanish).

${ }^{19}$ Henri Bergson, Euvres, Paris: Presses Universitaires de France, 1984; first edition, 1959 , p. 302.

${ }^{20}$ Henri Bergson, Matter and Memory, New York: Zone Books, 1991, p.165. 
limited to the scope of visual perception. It is "a matter of perception" whether one chooses to take this cue or not. But Jarmusch conveys that if you do so, you will take a sensory trip ${ }^{21}$.

These immanent invitations to a broader perception are most evident in the use of imaginary sounds in The Limits of Control, that is, sounds that go beyond a notion of realism: the moment Tilda Swinton's character, a mysterious blonde whose iconic appearance is later captured on a poster on the wall of an old picture house ${ }^{22}$, pours a glass of water, the act is enhanced by a sparkling sound $^{23}$. The gesture leading to the sound of sparkling water is repeated by Yūki Kudō on the train to Seville ${ }^{24}$. And a similar sound can be perceived in the close-up of diamond bracelets at the beginning as well as when Nude (Paz de la Huerta) opens her diamond-containing matchbox, stressing the value of the material $^{25}$. In all four instances, the imaginary sounds are distinct "sonorous objects" ${ }^{26}$. Each one is associated with a physical location - glass or diamond - but bears a quality of its own that transcends the actual image ${ }^{27}$.

Additionally, when perceived as a "sonorous object", these imaginary sounds enclose a reference. Concerning their mise-en-scène, the two glass scenes refer to the Coffee and Cigarettes episode "Jack Shows Meg His Tesla Coil", in which Meg White hits her cup with a spoon in order to demonstrate "earth as a conductor of acoustical resonance"28. In a second reference, the diamonds and the repeated quote "diamonds are a girl's best friend" 29 from Howard Hawks' 1953 musical comedy Gentlemen Prefer Blondes ${ }^{30}$ cast a distinct perspective on the intertext ${ }^{31}$. Each time Lorelei Lee (Marilyn Monroe)

\footnotetext{
${ }^{21}$ Cf. National Public Radio, "Director Jim Jarmusch Tests Limits in Control", Morning Edition, 8 May 2009. <http://www.npr.org/templates/story/story.php?storyId $=103902528>$ Accessed 30 May 2015.

${ }^{22}$ Jim Jarmusch, The Limits of Control (2009), Universum Film, 2009, 01:08:11 01:08:37.

${ }^{23}$ Ibid., 00:33:44-00:33:47.

${ }^{24}$ Ibid., 00:43:17 - 00:43:22.

${ }^{25}$ Ibid., 00:05:18 - 00:05:24 and 00:37:49-00:37:59.

${ }^{26}$ Pierre Schaeffer, "Acousmatics", Audio Culture: Readings in Modern Music, New York: Continuum, 2004.

${ }^{27}$ Just like the wax cylinder on which Manuel el Sevillano's guitar is recorded or the CD recording of Schubert must not be equated with the recording itself (cf. ibid., p. 80f).

${ }^{28} \mathrm{Jim}$ Jarmusch, Coffee and Cigarettes (2003), Kinowelt Film, 2005, 57:57 - 58:19. Cf. Sofia Glasl, Mind the Map, Marburg: Schüren, 2014, p. 98.

${ }^{29}$ Jim Jarmusch, The Limits of Control (2009), Universum Film, 2009, 00:05:16 00:05:26.

${ }^{30}$ Julian Rice addresses the reference to Gentlemen Prefer Blondes in a post-colonial reading in The Jarmusch Way, pp. 185-87.

${ }^{31}$ Julia Kristeva, "Word, Dialogue, and Novel", Desire in Language, New York: Columbia University Press, 1980, p. 66: "[A]ny text is the absorption and transformation
} 
gives a kiss to the shy Gus Esmond Jr. (Tommy Noonan), an imaginary sound can be heard, highlighting its "magic". The initial time this occurs is after the opening performance of the film, when Esmond Jr. appears backstage before Lorelei with a diamond ring, which is rewarded by a kiss that leaves him paralyzed. At the same time, by acknowledging the agency of the sonorous object, the magical quality of the kiss is subverted: puzzled by Lorelei's (mythical) effect on men, Dorothy (Jane Russell) remarks in passing: "I don't know what you do, honey, unless you use novocaine in your lipstick"32. The mention of an anesthetic foreshadows the grief of the one who is momentarily mesmerized by the magic of the kiss but who will suffer under his devotion later on in the narration. Accordingly, there is a time regime contained in the sonorous object, sonic evidence of different states - a memory. On the one hand, it is certainly a sonic joke, but on the other hand, this sound marks a presence in bliss and an unavoidable future in grief and jealousy, which will again have turned into past over the course of the film.

In The Limits of Control, the notion of past sounds resonating between molecules, brought up by the man with the violin, is revisited in the monologue of the stranger on the train to Seville (Yūki Kudō), who uses the matchbox for illustration:

In the near future, worn-out things will be made new again by reconfiguring the molecules. [...] Molecular detection will also allow the determination of an object's physical history. This matchbox, for example. Its collection of molecules could indicate everywhere it's ever been..$^{33}$

According to the woman, the universe consists of enclosed sets of molecules, a state that would enable a tracing of "an object's physical history" through analysis. Something similar can be encountered in the visual and sonic elements of a film, which are staged in a specific spatial and temporal order. The meaning of an object for the overall film may presently be obscure, but by analyzing the motif's mise-en-scène and its discussion in the film, different contexts can be related. Herein, the box stands in as a blank, attaining meaning through an intratextual relation - an "associative cluster"34.

of another. The notion of intertextuality replaces that of intersubjectivity, and poetic language is read at least double."

${ }^{32}$ Howard Hawks, Gentlemen Prefer Blondes (1953), Twentieth Century Fox, 2005, 00:01:25.

${ }^{33}$ Jim Jarmusch, The Limits of Control (2009), Universum Film, 2009, 00:43:23 00:43:52.

${ }^{34}$ William Freedman, "The Literary Motif: A Definition and Evaluation", Essentials of the Theory of Fiction, Durham and London: Duke University Press, 1988, p. 301. 
In the monologues, the matchboxes serve an emblematic function, drawing attention to distinct aspects of their immediate surroundings. Each encounter hints at an invisible dimension and introduces a template for perception. They instruct the protagonist's perception - and through him the perception of an implicit audience ${ }^{35}$. Consequently, after the matchboxes are opened, the contained notes are unfolded twice. In a literal sense, they open up to reveal an inscribed code, but the unfolding is also a symbolic one, as the subsequent scenography will take up cues from the monologues.

\section{Two Sides of the Same Plane}

During his stay in Madrid, the protagonist is led by these cryptic instructions to the Museo Nacional Centro de Arte Reina Sofía. In this archive of images, he encounters the subjects mentioned by the messengers on the surfaces of the canvases. Arriving at the national museum, he consults the floor plan in order to look at one specific exhibit only during each visit. Remarkably, the paintings foreshadow the characters who contact Lone Man in the following scenes: just before the conspiratorial meeting with Violin, the protagonist contemplates Juan Gris' El Violin (1916), following the first encounter's instruction to "watch for the violin" 36 . The man with the violin, then, will tell him to "wait with the girl"37. So during his second visit to the museum he looks at Roberto Fernández Balbuena's Desnudo (1922), and then encounters the aforementioned girl, Nude, lying on his bed in the tower building (Torres Blancas) ${ }^{38}$. While Felix the Cat calls out the shape his bag is supposed to assume in Ghost Dog, the encounters in The Limits of Control verbally anticipate what will take shape in the following scenes.

At the museum, the floor plan turns into a blueprint that serves as a substitute for a coherent string of events and guides Lone Man, like the coded messages contained in the matchboxes. At the same time, the distinction between the surfaces of the canvases and the scenography blurs. This gets most evident in the transition from a panoramic view from the roof terrace of Torres Blancas to a painting by Antonio López: Madrid desde Capitán Haya $(1987-96)^{39}$ : the protagonist walks into the frame, gazing into the distance. In a counter-shot, a panoramic view of Madrid appears. The image slowly zooms in on the view, getting out of focus, and is alternated twice with a close-up

\footnotetext{
${ }^{35}$ See Wolfgang Iser, The Implied Reader: Patterns of Communication in Prose Fiction from Bunyan to Beckett, Baltimore: Johns Hopkins University Press, 1974, p. 8 f.

${ }^{36} \mathrm{Jim}$ Jarmusch, The Limits of Control (2009), Universum Film, 2009, 00:05:56.

${ }^{37}$ Ibid., 00.22.14 - 00.22.19.

${ }^{38}$ Julian Rice analyzes the allusion to Jean-Luc Godard's Le Mépris (1963) in detail: Julian Rice, op. cit., pp. 24 and $192 f$.

${ }^{39} \mathrm{Jim}$ Jarmusch, The Limits of Control (2009), Universum Film, 2009, 00:26:43 00:27:45.
} 
of Bankolé, also in a zoom-in movement. In correspondence to the transition from rooftop to panorama, the running of water from the pool behind him is overlaid by non-diegetic delayed guitar sounds. As the image sharpens again in a zoom-out, the panorama has suddenly turned into a painting. The immersive movement of spatial transition is "thwarted" 40 at the very moment the frame appears, which now renders the panorama a painting. This epistemological shift is accentuated by the music, which up to this moment had provided a "sound bridge".

The setting has changed in a match cut, which in itself is not necessarily unconventional, especially since it is sutured by a sound bridge. But the way this match cut is staged is remarkable: it equates the filmic image with painting, blurs the limits between canvas and diegetic space, and effectively deconstructs the concept of depth of field - since both painting and film appear on a two-dimensional surface but create the illusion of the space they portray. Henceforth, both the cinematic and the painted image turn out to constitute two versions of a plane. This drastically expands the scope of the image. In addition, these images go beyond the distinction between foreground and background, which is swapped for a distinction between surface and context ${ }^{41}$.

Considering the role of painting in cinema, André Bazin distinguished "the frame of the painting" ("le cadre du tableau") from "the outer edges of the screen" ("les limites de l'écran") ${ }^{42}$ :

In other words the frame of a painting [le cadre du tableau] encloses a space that is oriented so to speak in a different direction [constitue une zone de désorientation de l'espace]. In contrast to natural space, the space in which our active experience occurs and bordering its outer limits, it offers a space the orientation of which is inwards, a contemplative area opening solely onto the interior of the painting.

The outer edges of the screen are not, as the technical jargon would seem to imply, the frame of the film image. They are the edges of a piece of masking $[\mathrm{cach}]$ that shows only a portion of reality. The picture frame polarizes space inwards. On the contrary, what the screen shows us seems to be part of something prolonged indefinitely into the universe.

\footnotetext{
${ }^{40}$ Jacques Rancière, Film Fables, Oxford: Berg, 2006.

${ }^{41}$ Herein, the paintings not only serve as a template for the following scenes but also, by the way they are staged, enable an approach Garrett Stewart calls "narratography". He writes in Framed Time: Toward a Postfilmic Cinema, Chicago: The University of Chicago Press, 2007, p. 27: "Where narratology concerns plot types and broad dynamic patterns, narratography is caught up in the local mechanics of interval and transition. Where cinematic narratology concerns the visual discourse of plot, filmic (or digital) narratography plots out the textualization of the image itself."

${ }^{42}$ André Bazin, Qu'est-ce que le cinéma ?, Paris: Cerf, 1990, p. 188; André Bazin, What Is Cinema? I, Berkeley: University of California Press, 2005, p. $165 f$.
} 
A frame is centripetal, the screen centrifugal. Whence it follows that if we reverse the pictorial process and place the screen within the picture frame, that is if we show a section of a painting on a screen, the space of the painting loses its orientation and its limits and is presented to the imagination as without any boundaries. ${ }^{43}$

When the panoramic image turns out to be composed only of cadres, the filmic image is no longer a cache for reality but centrifugal, an indefinite alteration of contingent planes. If "reality is arbitrary"44, as is repeatedly stated in The Limits of Control, cadre and cache become indefinable, constituting two sides of the same plane.

In Seville, the national museum is succeeded by the Torre del Oro. The golden tower appears in three different shapes or versions, each with distinct properties: as a miniature lamp (in the Seville apartment), as a representation (on a postcard), and as a monument at the Guadalquivir. "The tower may have been named for the gilded tiles that originally covered it or, as seems more likely, because it became a repository for the gold that Spain plundered from the Americas for three hundred years" ${ }^{\prime 4}$. Although the thick walls exhibit the difference between the monument's surface and arbitrary content, signifier and signified coincide in its shimmering, created by the sun's reflection on its former coating. Therefore, it is not quite clear whether the illumination of the miniature mimics the precious content or the reflection of the sun's rays. Nevertheless, the miniature of the Torre del Oro virtually encloses alternative explanations, projected onto a material object. The origin of the tower's name lingers both inside and outside of its walls.

The postcard, on the other hand, depicts the tower as a two-dimensional image, locating an abstract space between the real object and its reproduction, between light rays and dispositif ${ }^{46}$. In a shot in which the tower is shown behind the postcard, another dimension is added: both the tower and the photograph appear on an illuminated plane - a circumstance that, of course, is most evident in the cinematic situation, but holds true on any screen.

The matchboxes, the paintings, and the tower all adhere to a dialectics of surface and depth. During the encounters, the matchboxes function as a medium for instructions and illustrate the monologues. The paintings serve as a template, unfolding in depth in the succeeding scenography. And the

\footnotetext{
${ }^{43}$ Ibid., p. $165 f$.

${ }^{44} \mathrm{Jim}$ Jarmusch, The Limits of Control (2009), Universum Film, 2009, 00:06.04; 01:39:12.

${ }^{45}$ Rice describes the tower as a symbol for Spanish imperialism and links it to "the current global dominance of the United States", personified in Bill Murray's American. Julian Rice, op. cit., pp. 25-27.

${ }^{46}$ See Jean-Louis Baudry, "Le dispositif: approches métapsychologiques de l'impression de réalité ”, Communications 23, 1975, pp. 56-72.
} 
Torre del Oro provides an architectural structure, which can be depicted in a two-dimensional reproduction or a miniature, alluding to different semantic contexts. Thus, the enigmatic tower creates an imaginary space. The implicit question about the configuration of imaginary spaces finally culminates in the circumstances of the death of American (Bill Murray). It is entangled with the question of how Lone Man was able to intrude into and escape from a hermetically sealed room.

On the afternoon prior to his intrusion, the protagonist studies a blueprint of the American's fortress and a map. In comparison to the chart and the cartographed area in the scene, the map attains depth ${ }^{47}$. Herein the map is in line with the floor plan in the museum and the postcard of the Torre del Oro. While the map and the floor plan provide spatial orientation, the postcard depicts the tension between "original" and reproduction. So when Lone Man, after having studied the structure of the house and the surrounding area, is suddenly inside the house and no longer outside, the montage is complementary to the cut from the panorama of Madrid to Antonio López's painting: once again, there are alternating shots of Lone Man and a point of view, followed by a sudden change of location ${ }^{48}$. Once again, the image's scope expands. And when the protagonist switches on a lamp that looks exactly like the one in his apartment, he has turned the alternate explanations for the tower's name - a reflection on its content as opposed to a reflection of the sun, that is, metonimy vs. the literal - into an actual spatial inversion. There is no reason the protagonist should not be able to access an enclosed space just as easily as he observes its blueprints. Since surface and enclosed space can be inverted by a trick of the mind - triggered by montage and a sound bridge - the categories of interior and exterior have become obsolete. Hence, The Limits of Control does not entertain a realistic idea of coherence but a prevailing logic of sound, bridging and even inverting settings, previously provided in the monologues of the conspirators.

However, a logic to the intrusion may be traced back to John Boorman's Point Blank (1967) as explanatory intertext, hinted at by the name of Jarmusch's production company and the phantom-like quality of both movies' central characters. In order to confront his former partner, who betrayed him and left him for dead, Walker (Lee Marvin) ascends the heavily guarded apartment complex completely unnoticed. A subtle visual joke during these episodes lies in the arrows that repeatedly point at Walker and the center of the guards' ignorance ${ }^{49}$.

\footnotetext{
${ }^{47}$ Jim Jarmusch, The Limits of Control (2009), Universum Film, 2009, 01:30:33 01:30:50.

${ }^{48}$ Ibid., 01:35:14 - 01:36:30.

${ }^{49}$ John Boorman, Point Blank (1967), Warner Home Video, 2005, 00:46:29, 00:46:43, and $00: 51: 34$.
} 
So far, three different modes of "enclosed spaces" have been distinguished. Firstly, a mode of intertextual depth supplying a context and a reading, such as the passages from the Hagakure in Ghost Dog, or the sonic allusions in The Limits of Control. Herein, seemingly enigmatic elements in the film carry the latent potential of an enhanced perspective on the film. Secondly, verbal instruction: the fellow conspirators Lone Man encounters on his trip supply him with directions for conscious perception and outline the succeeding scenography. By supplying these templates, the monologues' content blends with the following scenography. Thirdly, visual and sonic cues, which, on the one hand, again hint at intertexts but, on the other hand, create intratextual relations. Herein the paintings. at the Centro del Arte as well as the Torre del Oro introduce a dialectics of surface and depth. These audiovisual enclosures unfold an underlying dimension as a coherent motif over the course of the film. This fourth dimension - time - is developed more thoroughly in the second half of the movie.

\section{Folding of the Surface}

The temporal dimension of audiovisual enclosures in The Limits of Control becomes particularly prominent during the train ride back to Madrid. In front of a reflecting window, which places him simultaneously in the train and outside, Lone Man takes a piece of paper from the last matchbox, which remains blank ${ }^{50}$. On the one hand, this may suggest the fulfillment of his task, after which there remains no further instruction ${ }^{51}$. But on the other hand, its blankness directs attention to the piece of paper itself and will lead him back to the Museo Reina Sofía and to Antonio Tàpies' Gran Sábana, better known as Gran llençol (Large Sheet, 1968).

The return to the museum is both a return to an already familiar place and a movement back in time, as the museum first reappears in a reversed exterior shot. In the reflection of the metal outer wall, people and cars can be seen moving backward. Inside, Lone Man takes the mandatory look at the floor plan and finally sits down in front of Tàpies" "painting"/ "collage". The sheet on the canvas resembles the one under which he found the dead body of Nude prior to his intrusion into the domicile of the American. On Gran Sábana the cadre has regained its centripetal force, solidifying the soft quality the sheets had at the house from which Lone Man set out to kill ${ }^{52}$.

\footnotetext{
${ }^{50}$ Jim Jarmusch, The Limits of Control (2009), Universum Film, 2009, 01:41:00 01:42:07.

${ }^{51}$ Fabienne Liptay, "“The Limits of Control'. Understanding Cinema Beyond Signs and Meaning", Habitus in Habitat II: Other Sides of Cognition, Sabine Flach and Jan Söffner (eds.), Bern: Peter Lang, 2010, p. 237.

${ }^{52} \mathrm{Jim}$ Jarmusch, The Limits of Control (2009), Universum Film, 2009, 01:27:10 01:27:14.
} 
The structure of the sheet on canvas (cadre) bears the trace of a specific spatiotemporal context ("orientation"), which unfolded over the discours of the film. In its solidification, it hints at an infinite space for "imagination". Reversing cache to cadre, the canvas wrapped in a sheet translates into the plastic sheet on the canvas. What makes this reversal possible and reproduces the process is "the ineffable element of the dream within the machine" "through which time becomes material".

After Lone Man has taken out the piece of paper from the matchbox on the train to Madrid, he unfolds it, turns it around, and finally holds it out on his hand. Looking like a miniature mountain, the folded scrap of paper mirrors the hills passing by in front of the train's window. Over a distinct period of time, the flat piece of paper gains a third dimension by being folded. Without inscription it is no longer a code but the piece of paper - the medium itself - that is of importance. As the train glides through a rocky landscape, it resembles the landscape behind the window, before it is again enclosed in a matchbox, which once served to illustrate a resonating body, a concept of acoustic memory, and as a model for the inversion of spaces. In capturing the entire process of folding from beginning to end, an immediate feeling of time is created and rendered visible, represented by the coherence of the act, the unfolding of an event. While otherwise audiovisual ideas - linked to the matchbox - are only implicitly present throughout the rest of the film, the act of folding becomes a metaphor for the reversibility of spaces, of exterior and interior, or of an idea and its actualization ${ }^{53}$.

When Lone Man ultimately throws the last matchbox - containing the receipt for the locker in which he stored his bag - into a wastebasket at the end of The Limits of Control, not only has his trip come to an end, but in this gesture he brings the film to closure.

\footnotetext{
${ }^{53}$ See Gilles Deleuze, The Fold: Leibniz and the Baroque, London: Athlone Press, 1993, p. 22f: "[T] he whole world is only a virtuality that currently exists only in the folds of the soul which convey it, the soul implementing inner pleats through which it endows itself with a representation of the enclosed world."
} 


\section{Bibliography}

André, Emmanuelle. Esthétique du motif. Cinéma, musique, peinture. Paris: Presses Universitaires de Vincennes, 2007.

Baudry, Jean-Louis. "Ideological Effects of the Basic Cinematographic Apparatus", trans. Alan Williams, Film Quarterly, 28.2, 1974, pp. 39-47 ["Effets idéologiques produits par l'appareil de base", Cinéthique 7/8 (1970), pp. 1-8].

- "Le dispositif: approches métapsychologiques de l'impression de réalité", Communications, 23, 1975, pp. 56-72.

Bazin, André. Qu'est-ce que le cinéma ? Paris: Éditions du Cerf, 1990 [1958-1962].

- What Is Cinema? I, Hugh Gray (ed.). Berkeley: University of California Press, 2005.

Bergson, Henri. Euvres, André Robinet (ed.). Paris: Presses Universitaires de France, 1984 [1959].

- Matter and Memory, trans. Nancy Margaret Paul and W. Scott Palmer. New York: Zone Books, 1991 [Matière et mémoire, 1896].

Böhme, Hartmut. Fetishism and Culture: A Different Theory of Modernity, trans. Anna Galt. Berlin and Boston: Walter de Gruyter, 2014 [Fetischismus und Kultur: Eine andere Theorie der Moderne, 2006].

Boorman, John. Point Blank (1967), Warner Home Video, 2005.

Burke, Kenneth. A Rhetoric of Motives. New York: Prentice-Hall, 1950.

Canemaker, John, Felix: The Twisted Tale of the World's Most Famous Cat, New York: Da Capo Press, 1996.

Deleuze, Gilles. Cinema II. The Time-Image, trans. Hugh Tomlinson and Robert Galeta. Minneapolis: University of Minnesota Press, 1989 [Cinéma 2. L'Image-temps, 1985].

— The Fold: Leibniz and the Baroque, trans. Tom Conley. London: Athlone Press, 1993 [Le Pli. Leibnitz et le Baroque, 1988].

Engell, Lorenz and André Wendler. "Medienwissenschaft der Motive", Zeitschrift für Medienwissenschaft, 1, 2009, pp. 38-49.

Epstein, Jean. "L'intelligence d'une machine", trans. Trond Lundemo, Jean Epstein: Critical Essays and New Translations, Sarah Keller and Jason N. Paul (eds.). Amsterdam: Amsterdam University Press, 2012, pp. 311-315.

- L'intelligence d'une machine. Paris: Éditions Jacques Melot, 1946.

Film Society of Lincoln Center. "Archival Talks: Jim Jarmusch, The Limits of Control", 30 October 2009. <https://www.youtube.com/watch? $\mathrm{v}=\mathrm{v} 62 \mathrm{aGp0v64k}>$ Accessed 31 May 2015.

Freedman, William. "The Literary Motif: A Definition and Evaluation" [1971], Essentials of the Theory of Fiction, Michael J. Hoffman \& Patrick D. Murphy (eds.). Durham and London: Duke University Press, 1988, pp. 299-312.

Freud, Sigmund. The Standard Edition of the Complete Psychological Works of Sigmund Freud IV.1, James Strachey (ed.). London: Hogarth Press, 1964.

Glasl, Sofia. Mind the Map. Jim Jarmusch als Kartograph von Popkultur. Marburg: Schüren, 2014.

Hawks, Howard. Gentlemen Prefer Blondes (1953), Twentieth Century Fox, 2005.

Iser, Wolfgang. The Implied Reader: Patterns of Communication in Prose Fiction from Bunyan to Beckett. Baltimore: Johns Hopkins University Press, 1974 [Der 
implizite Leser: Kommunikationsformen des Romans von Bunyan bis Beckett, 1972].

Jarmusch, Jim. Coffee and Cigarettes (2003), Kinowelt Home Entertainment, 2005.

— Ghost Dog (1999), Kinowelt Home Entertainment, 2005.

- The Limits of Control (2009), Universum Film, 2009.

Kristeva, Julia. "Word, Dialogue, and Novel", trans. Thomas Gora, Alice A. Jardine and Léon S. Roudiez, ["Bakhtine, le mot, le dialogue et le roman", 1967], Desire in Language. A Semiotic Approach to Literature and Art, Leon S. Roudiez (ed.). New York: Columbia University Press, 1980, pp. 64-91.

Liptay, Fabienne. " 'The Limits of Control'. Understanding Cinema Beyond Signs and Meaning", Habitus in Habitat II. Other Sides of Cognition, Sabine Flach \& Jan Söffner (eds.). Bern: Peter Lang, 2010, pp. 227-248.

Mottram, James. "Theme and Variations", Sight and Sound, 20.1, 2010, p. 16.

National Public Radio. "Director Jim Jarmusch Tests Limits in Control", Morning Edition, 8 May 2009. <http://www.npr.org/templates/story/story. php?storyId=103902528> Accessed 30 May 2015.

Peirce, Charles S. The Writings of Charles Sanders Peirce: A Chronological Edition - Volume V (1884-1886), Max H. Fisch (ed.). The Peirce Edition Project, Bloomington: Indiana University Press, 1993.

Rancière, Jacques. Film Fables, trans. Emiliano Battista. Oxford: Berg, 2006 [La Fable cinématographique, 2001].

Rice, Julian. The Jarmusch Way: Spirituality and Imagination in Dead Man, Ghost Dog and The Limits of Control. Lanham: Scarecrow, 2012.

Schaeffer, Pierre. "Acousmatics" [Traité des objets musicaux, 1966], trans. Daniel W. Smith, Audio Culture: Readings in Modern Music, Christoph Cox and Daniel Warner (eds.). New York: Continuum, 2004, pp. 76-81.

Stewart, Garrett. Framed Time: Toward a Postfilmic Cinema. Chicago: The University of Chicago Press, 2007.

Suárez, Juan Antonio. Jim Jarmusch. Urbana and Chicago: University of Illinois Press, 2007.

Swinton, Tilda. "A Letter to a Boy from His Mother", Critical Quarterly, 48.3, 2006, pp. 110-120, 2006. 